\title{
The Influence of Compensations and Social Assurance on Job Performance: Study on Contract Employees' Palm Company
}

\author{
Rahmi Widyanti \\ Fakultas Ekonomi \\ Universitas Islam Kalimantan (Uniska) \\ Banjarmasin - Indonesia \\ rahmiwidyanti@yahoo.com
}

\author{
Basuki \\ Prodi Manajemen \\ Sekolah Tinggi Ilmu Managemen Indonesia (STIMI) \\ Banjarmasin - Indonesia \\ Basuki.stimi.bjm@gmail.com
}

\begin{abstract}
Compensation is any form of payment to employee for work they provide their employer, including social assurance. The purpose of this study to examine and analyze the influence of compensations and social assurance to its impact on improving job performance of employees'. The research was conducted by using a quantitative approach that forms the causal relationship between variables. This is one palm company in Kapuas District. The number of samples used in this study amounted to 51 contract employees' with census sampling technique. The data analysis technique are used in this study are grouped into two, namely descriptive statistics analysis techniques and inferential statistical analysis techniques by using SPSS for Windows. This study found that compensation and the social assurance are high, both can give an increase in job performance of contract employees' in Kapuas District. This study could accommodate all the hypothesized both of compensations and social assurance by companies able to deliver significant improvements to the job performance
\end{abstract}

Keywords- Kapuas Indonesia, compensations, social assurance and job performance

\section{INTRODUCTION}

Compensation system generally is seen as an instrument for distributing to employees, the distribution of is based on production, time work, agencies and based on their needs [1]. Most organizations used compensations to defined organizational goals and motivate employee performance to one achieve them [2], including social assurance. Social assurance given by a company would provide security and a feeling of security to workers [3].

Performance is part duty rate of a result of working should be given workers to employer. High performance of employees, companies should aware of compensation and social assurance is a driving in achieving productivity, because with the high productivity it is capable of ensuring survival company [2]. Company palm largest in Kapuas District this employing two types of employees namely permanent employees and contract employees. Pay system different between both employees it causes the problem in of employee performance, so we needed researched how the influence of compensation and social assurance of the contract employees performance.

\section{LITERATURE REVIEW}

\section{A. Previous Research}

Results of previous research shows that there are significant influence between compensation and social assurance against employee performance, although using different respondents and measuring instrument. Setiaji in his research found compensastion used wage and social assurance influence on job productivity [4]. Research of Yemoah et al found compensation could increasing the job performance [2], Result study of Wikesa is used intrinsic rewards and extrinsic reward has an effect on performance the secondary school teacher [5], the result of Lai Hsi found with good compensation design influence employee satisfaction and performance [1].

\section{B. Framework of Research.}

Compensation as a reward or gained to services to be provided a company to employees to increased job motivation and technique ability, theoretical, conceptual and moral employees in accordance with their needs work. So enter that compensation aimed at improving spirit and passion work employees to give the results of maximum for the company, while social assurance aims to improve security and satisfied with corporation for job employee implementation [7].

Employee performance was a result of working individual or group that appeared after effort is done with unification of the incentives work is in a person with their ability to carry out a job [2]. Compensation influence employee's performance [8]. Similar with the statement, [6] this study also found that compensation and social assurance in simultaneous and partial contribute significantly to work performance employees. So the thought was the research is that compensation and assurance have a significantly to employees performance whether partial and together. 


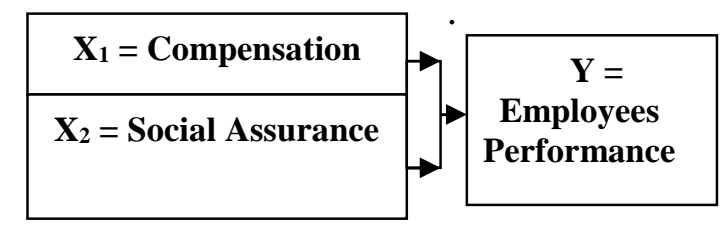

Fig. 1. Framework of Research

\section{RESEARCH METHODOLOGY}

This research is explanatory research with the approach causality, is research who want to seek explanation in the form of cause and effect relationship (cause-effect) among some concept or several variables or several strategies developed in the management [8], [9]. The population in this research are contract employees to a palm company in kapuas district which totaled 51 people, while the sample is not done the sample collection in this research as all respondents population be used as criteria as follows:

- Has become an employee contract at more 2 (two) year

- Productive age (less than 55 years old) 20.

Statistical tests using program spss for windows version

\section{RESUlt AND DisCUSSION}

\section{A. Hyphoteses Test Result}

Based on the calculation of statistics tests obtained the calculation on regression analysis linear simple obtained constant of 9,642 and score direction regression compensation (X1) as much as 0,382 , so obtained equation a line regression is: $\mathrm{Y}=9,642+0,426 \mathrm{X} 1$. This means that employee performance without supported compensation (constant) the 9,642 and any change/increase variable compensation will determine much of the employee performance, every time there was hike one points on the variables of compensation led the increasing the score performance variables employees of 0,426 . This result supported the statement compensation is one of the most important to influence performance [10]

The calculation on regression analysis linear simple obtained constant of 8,845 and a score direction regression social assurance (X2) as much as 0,539 , so obtained equation the regression line is: $\mathrm{Y}=8,845+0,539 \mathrm{X} 2$. This means that employee performance without supported social assurance (constant) 8,845 and any change/increase variable social assurance will determine much of the employee performance, every time there was hike one points on the variables of social assurance led the increasing the score performance variables employees of 0,539 . This result supported the statement is social assurance could impact on employee performance [4].

Based on the calculation of statistics obtained value $\mathrm{F}$ count $=34,048$ with significance of $F 0,000$. The significance used 5 percent this value chart with df $1=2$ and df $2=n-k-1=$ $51-2-1=48$ obtained $\mathrm{f}$ table of 3,19 . So F count $(34,048)$ were greater than $F$ table $(3,19)$. Thus hypothesis said that there was influence simultaneously between compensation (X1) and social assurance (X2) of employee performance (Y) acceptable. And receiving hypotheses third or test the simultaneous, means level of employee performance be very much determined by compensation and social assurance. This fact can be understood that compensation employees is one of the factors important in supporting of employee performance, so are social assurance that is one the key success of employee performance [2] and [4]

\section{B. Discussion}

Based on the respondents answer had of compensation the results compensation employees at company palm in Kapuas District was already carried out well, because based on the respondents answer as a whole to items questions compensation variable with a score of average ranged from 2,97 s.d.3,32, while seen from the average score variable compensation is of 3,04 , that means that most of respondents said they agreed that compensation already provided well. The results of the testing of hypotheses first namely compensation influence significance of the performance of employees proven. The result of this research in similar with the results of research conducted by Yamoah [2] and [5] that shows a positive relationship and significant between compensation with the performance of employees, compensation is it services companies should perceived fair to employees and the size of the compensation must be in accordance with hope employees.

Similar with this study, [10] compensation system is one of the most important potential in order to influence performance, [11] because compensation is total reward given to the employees as a return for their hard work.

Social assurance given a company to a contract employees considered to have already good by employees. This seen from the results of the respondents answer, social assurance given a company to a contract employee was already carried out. This can be seen from of the respondents answer as a whole to items questions variable social assurance between 2.88 s.d.3.25. Based on the average score variable social assurance is 3,02 , so that means that most of respondents said they agreed that social security already provided well. The results of the testing of hypotheses both the social security impact on of employee performance proven. This study shows that the better social assurance given a company to an employee the good of employee performance. Social assurance it is a guarantee protection afforded the company of loss of income employees by the accident work, illness or length of employment who had been discharged [3].The results of the study supporting previous research [3] and [9].

The testing hypotheses, simultaneously that statement to suspect that compensation variable and social assurance variable give a significant contribution to employee performance at companies in Kapuas District acceptable the first significant (a) $=0,05(5 \%)$ to the value of the regression coefficient from $=0,766$ and probability of $(\mathrm{p})=0,030$ less than 0.05 and $\mathrm{R}^{2}=0.587$, are positive .5867 , this means that $58,67 \%$ fluctuations in the employee performance can be caused by compensation variable and social assurance 
variable, while is $41,33 \%$ caused by other variables outside of this study. This result supported the study of Lai Hsi [1] and Setiaji [4].

\section{CONCLUSION AND SUGGESTIONS}

\section{A. Conlusion}

Based on the results of the analysis that has been done, it can be taken a conclusion that when compensation and social assurance given with good will can have an influence positive on of employee performance contract. Whether partial and simultaneously.

\section{B. Suggestions}

Based on the results of the analysis it is suggested that in order to increase performance employees, manager is expected to more attention to social assurance contract employees so what is desire and hope employees understandable and use it as a means of in achieving the target company.

For future research, enrichment of the results of research it can be carried out by applying model this research on sample which is large and heterogeneous, also on employment different status (outsourcing or permanent employees) are so that the result of obtained can reveal a difference in the treatment that must be considered company in treating an employee with employment different status (permanent employee or contract employees).

\section{REFERENCES}

[1] Hsin-Hsi Lai, "The influence of compensation system design on employee satisfaction", African Journal of Business Management, 2011, Vol. 5(26), pp. 1071810723.
[2] Yamoah, Emmanuel, Erastus, "Relationship between Compensation and Employee Productivity", Singaporean Journal of Business Economics, And Management Studies, 2013, Vol.2, No.1.

[3] Charlesworth, Sara and Marshall, Helen,"Sacrificing Workers? The curious case of salary sacrificing in nonprofit community services in Australia" International Journal of Public Sector Management, 2011, Volume 24, No.7, pp.673-683.

[4] Setiaji, "Pengaruh Upah dan Jaminan Sosial terhadap Produktivitas Kerja Karyawan PT. Sumber Makmur Semarang", 2009, Undip Semarang.

[5] Wekesa, Jane Nelima, Silas Nyaroo.M.A, "Effect of Compensation on Performance of Public Secondary School Teachers in Eldoret Municipality Kenya”, International Journal of Scientific and Research Publications, 2013, Volume 3, Issue 6.

[6] Useem, Michael and Andrea, "Exceptional Frontline Performance: Learning from the Medal Honor Tradition, Organizational Dynamic, 2014, 43, pp.37-43

[7] Sugiyono, "Metode Penelitian Bisnis", Erlangga, 2006, Jakarta.

[8] Singarimbun, Masri dan Effendi, Sofyan. 2006. Metodologi Penelitian Survey. LP3ES, Jakarta.

[9] Bebchuck, L.A. and J.M.Fried, "Executif compensastion as an agency problem, Journal of Economics Perspective", 2003, 17(3):71-92.

[10] Burn, N.S.K., "The impact of performance-based compensastion on misreporting", Journal of Financial Economic, 2006, 7(9):35-67

[11] Epstein, G.S., "Perceived Income, Promotion and Incentive Effect", International Journal of Manpower, 2006, Volume 27, No. 2, pp.104-125.

[12] Cushway, Barry, "Human Resource and Management, The Association for Management Educational and Development", 2004, London.

[13] Dessler, Gary, "Manajemen Sumberdaya Manusia, 2007, Prentice Hall, Indonesia. 